\title{
A Borer-Specific Assessment Scheme for Identifying Sentinel Trees to Delimit Invasive Borers in Urban Forests
}

\author{
Gabriel P. Hughes, Clifford S. Sadof, and Matthew D. Ginzel
}

\begin{abstract}
Aggressive insects like the emerald ash borer [Agrilus planipennis (Fairmaire)] (EAB) increasingly threaten the health of the urban forest. Early detection of exotic wood-boring pests is critical for rapid response efforts, and allows for effective management while populations are relatively low. During street tree inventories, arborists record subjective rankings of tree condition and pest incidence; however, the extent of insect attack is rarely quantified. Moreover, it is unknown how the assessment of tree vigor provided by city foresters during these inventories relates to the likelihood of wood-borer infestation. In this study, researchers developed a borer-specific tree vigor assessment scheme to rapidly evaluate street trees, and to identify when EAB populations begin to grow exponentially based on the health of the forest. This scheme incorporates common indicators of EAB attack, including canopy thinning and epicormic sprouts, as well as attack by common native wood-boring insects. This scheme was used to track the health of ash trees from 2010 to 2013 in one urban forest with advanced symptoms of EAB decline and one without (Indianapolis and Lafayette, Indiana, U.S., respectively). Trees declined more rapidly in Indianapolis where emergence holes from native borers were positively correlated with EAB in infested areas. Over the course of the study, first detections of EAB occurred on progressively weaker trees at both sites, suggesting that early detection of incipient EAB populations can be improved by surveying apparently healthy trees.

Key Words. Agrilus planipennis; Early Detection-Rapid Response; Emerald Ash Borer; Surveys; Tree Inventory; Tree Vigor; Wood Borers.
\end{abstract}

The introduction of aggressive exotic wood-boring pests into the United States is forcing urban forestry managers to consider innovative approaches for maintaining forest health. On a small scale, endemic woodborers killing already weakened trees can be managed through a combination of insecticides and cultural control methods to improve tree vigor (Herms et al. 2014). Alternatively, weakened trees containing borers can be removed and replaced with less susceptible tree species. Yet, the invasion of more aggressive exotic borers, like the Asian longhorned beetle [Anoplophora glabripennis (Motchulsky) (Coleoptera: Cerambycidae)] and the emerald ash borer [Agrilus planipennis (Fairmaire) (Coleoptera: Buprestidae)], threaten a substantially larger part of the urban canopy than ever before. In fact, recent surveys of 12 eastern North American cities indicate that urban forests could lose between $30 \%$ and $70 \%$ of their standing trees to these destructive pests (Raupp et al. 2006).
The emerald ash borer (EAB) originated from Asia, where it preferentially attacks stressed trees in the genus Fraxinus (Yu 1992). In North America, however, it is capable of killing even apparently healthy ash trees in as little as three years after initial colonization (Poland and McCullough 2006; Knight et al. 2013). Adults emerge May-July and feed on leaves in the canopy before mating and laying eggs (Cappaert et al. 2005; Lyons and Jones 2005; Liu et al. 2007; Wang et al. 2010). Since its detection in North America in 2002, EAB has killed millions of green, white, and black ash trees, and is expected to cause more than USD $\$ 10$ billion in damage in urban areas over the next decade (Kovacs et al. 2010). Human-assisted spread of EAB has compounded the problem, as people unwittingly transport infested logs or ash nursery stock to new locations (Haack et al. 2002; Cappaert et al. 2005). Early in an invasion, emergent $\mathrm{EAB}$ populations go undetected because affected trees appear vigorous and show no 
signs of decline (Haack et al. 2002; Cappaert et al. 2005; Poland and McCullough 2006). Often, EAB is detected in an area only after trees have begun showing symptoms of invasion (e.g., crown dieback and epicormic shoots) and, by this time, the population has usually expanded to the level where local eradication efforts via tree removal and treatment is prohibitively expensive and labor intensive (Cappaert et al. 2005; Poland and McCullough 2006).

The success of management programs to maintain the health and utility of urban ash resources depends on the early detection of $\mathrm{EAB}$ and a rapid response (McCullough and Mercader 2012). Such a response to $\mathrm{EAB}$ invasions may be hampered, however, by limitations in current detection methods for EAB, including purple prism traps, girdled trap trees to attract and capture flying adults, and visual surveys. Purple prism traps baited with ash volatiles are commonly used in monitoring programs (Crook et al. 2008; de Groot et al. 2008), and are sensitive enough to allow for detection of EAB as early as one year after its introduction to a new area (Knight et al. 2013). Girdled trap trees are also effective monitoring tools because stressed trees are generally more attractive to EAB (McCullough et al. 2009a; McCullough et al. $2009 \mathrm{~b})$. However, these methods provide little information about which trees have been attacked or the rate at which ash trees are likely to decline in the community. Visual surveys, on the other hand, have the potential to provide critical information regarding which trees are attacked, but signs and symptoms of EAB infestation often do not appear until trees are heavily infested (Cappaert et al. 2005).

Urban foresters routinely conduct street tree inventories to develop plans to improve forest health and manage hazards resulting from failing trees. During these inventories, each tree is often assigned a health ranking that indicates the overall condition of the tree. However, it is unclear how this assessment of tree health relates to the likelihood of EAB infestation. Objectives of the current study were to 1) determine borer-associated characteristics of tree decline that predispose native ash trees to attack by $\mathrm{EAB}$, and 2) relate these characteristics to rates of ash decline in urban forests infested with EAB to develop an assessment-based detection method. Such a tool will leverage current street tree inventories, by enabling affordable and sensitive early detection of $\mathrm{EAB}$, and empower urban forest- ers to catalyze community support for early intervention of $\mathrm{EAB}$ populations to save their ash trees.

\section{MATERIALS AND METHODS}

\section{Borer-Specific Assessment Scheme}

A borer-specific assessment scheme was developed to enable urban foresters to identify trees most likely to come under attack by borers. The assessment scheme was based on two individual ranking schemes of tree vigor: 1) the International Society of Arboriculture scheme (ISA 2013), and 2) The Davey Tree Expert Company scheme (Zelaya, pers. comm.). The first scheme was chosen because it is most widely used by consulting arborists. The other scheme was chosen because of its capacity to rate the occurrence of specific symptoms of tree stress to better predict the presence of borers. Initial tree rankings consisted of Good, Fair, or Poor, following the vigor classes outlined by the ISA scheme. Trees rated "Excellent," "Very good," "Critical," and "Dead" were excluded from the analysis because trees of these conditions are typically rare in urban landscapes. Trees in the "Critical" and "Dead" categories pose an unacceptable risk in most urban landscapes, and are often removed by arborists, while the stresses of urban environments often preclude trees in the "Excellent" and "Very good" categories. In fact, a recent survey of ash in the City of Indianapolis indicated that trees in these categories represented $<2 \%$ of the total ash trees (Peper et al. 2008). Each tree was rated according to those aspects of tree ranking schemes that are most likely to indicate the presence of borers, including crown thinning, biotic factors, and structural problems (Table 1). Vigor class was assigned according to the lowest ranking in any category. For example, a tree with no sign of borers, a full crown, but minor structural damage would be rated "Fair." Woodpecker markings and epicormic shoots were rated as absent (Good), present (Fair), or abundant (Poor/Critical).

\section{Experimental Design}

The study began in 2010 at two sites: Lafayette, Indiana (Tippecanoe County) where EAB was absent, and Indianapolis, Indiana (Marion County) where EAB was first detected in 2006, and the population was established and growing. In June, after 
peak emergence of $\mathrm{EAB}$, researchers used their assessment scheme to rate ash trees, and selected approximately equal numbers of Good, Fair, and Poor trees at each site. One hundred fifty-nine trees were rated in Lafayette and were comprised of 71 Good, 52 Fair, and 36 Poor trees at four locations (Table 2). In Indianapolis, 151 trees comprised of 45 Good, 58 Fair, and 48 Poor trees at four locations (Table 2). Trees were rated using the researchers' assessment scheme, and their growth measured each year in June for four years through 2013 (Table 2) to track the health of the urban forest at each site. DBH of each tree was measured to determine the extent to which size influenced EAB attack (Marshall et al. 2009; McCullough et al. 2009a; McCullough et al. 2009b). Trees were between 14 and $40 \mathrm{~cm} \mathrm{DBH}$, which represents the median class of street trees at the two study sites (Peper et al. 2008; Shaw pers. comm.).

The abundance of common wood borers was quantified in each of the 310 trees. The number of insect emergence holes on the basal two meters of each tree were counted to monitor insect attack over the course of the study. A similar method has been used to rapidly estimate the density of the cerambycid Enaphalodes rufulus, the red oak borer (Fierke et al. 2005). Each year, researchers marked holes with a different color of enamel paint (The Testor
Corporation, Rockford, Illinois, U.S.) to track the annual emergence of borers from 2010 to 2013. Specifically, researchers monitored for emergence holes created by the redheaded ash borer (Neoclytus acuminatus), eastern ash bark beetles (Coleoptera: Curculionidae, Hylesinus spp.), clearwing moths (Lepidoptera: Sessidae, Podesia spp.), carpenter worms (Lepidoptera: Cossidae, Prionoxystus spp.), and EAB. Each borer creates an emergence hole of diagnostic shape and size, which allowed the quantifying of emergence holes by insect taxon.

\section{Statistical Analysis}

All statistical analyses were conducted in Statistica Version 10 (StatSoft Inc. 2011). To determine the rate of ash decline, the vigor class of all trees at each site and in each year was compared using Friedman ANOVA. Kaplan-Meier survival curves were calculated using June 2010 as the beginning of the study and June 2013 as the end (Kaplan and Meier 1958). Trees that declined to the Critical vigor class were considered censored data in the analysis because they were physically removed for safety reasons. A log-rank test was performed to compare the rate of decline between the two sites.

To determine the extent to which vigor class affects first detectable colonization of a tree by EAB,

Table 1. EAB-specific assessment scheme.

\begin{tabular}{|c|c|c|c|c|}
\hline \multirow[t]{2}{*}{ Category } & \multicolumn{4}{|c|}{ Vigor class } \\
\hline & $\overline{\text { Good }}$ & Fair & Poor & Critical \\
\hline Biotic factors & $\begin{array}{l}\text { No significant } \\
\text { damage }\end{array}$ & $\begin{array}{l}\text { Damage is evident } \\
\text { but from a non-fatal } \\
\text { causal agent }\end{array}$ & $\begin{array}{l}\text { Damage is significant } \\
\text { and by a potentially } \\
\text { fatal agent }\end{array}$ & $\begin{array}{l}\text { Damage is probably fatal; } \\
\text { tree is unsalvageable }\end{array}$ \\
\hline Crown condition & $\begin{array}{l}\text { Full, balanced, } \\
<10 \% \text { thinning }\end{array}$ & $\begin{array}{l}\text { Imbalance is evident, } \\
10 \%-30 \% \text { thinning }\end{array}$ & $\begin{array}{l}\text { Imbalance is significant, } \\
30 \%-80 \% \text { thinning }\end{array}$ & $\begin{array}{l}\text { Crownless, } \\
>80 \% \text { thinning }\end{array}$ \\
\hline Structural problems & None & $\begin{array}{l}\text { Minor, or if tree appears } \\
\text { to have been topped }\end{array}$ & Significant & Major \\
\hline
\end{tabular}

Table 2. List of sites and locations of trees, and dates each year when evaluations were performed.

\begin{tabular}{|c|c|c|c|c|c|}
\hline Site & Coordinates & 2010 & 2011 & 2012 & 2013 \\
\hline Lafayette, Indiana, U.S. & & June 23 & June 22 & June 13 & June 14 \\
\hline Sagamore Parkway & $40^{\circ} 27^{\prime} 11.2^{\prime \prime} \mathrm{N}, 86^{\circ} 54^{\prime} 39.3^{\prime \prime} \mathrm{W}$ & & & & \\
\hline Greenbush Street & $40^{\circ} 25^{\prime} 48.8^{\prime \prime} \mathrm{N}, 86^{\circ} 53^{\prime} 23.1^{\prime \prime} \mathrm{W}$ & & & & \\
\hline Downtown & $40^{\circ} 25^{\prime} 12.0^{\prime \prime} \mathrm{N}, 86^{\circ} 53^{\prime} 36.2^{\prime \prime} \mathrm{W}$ & & & & \\
\hline Tippecanoe Mall & $40^{\circ} 23^{\prime} 31.0^{\prime \prime} \mathrm{N}, 86^{\circ} 51^{\prime} 05.9^{\prime \prime} \mathrm{W}$ & & & & \\
\hline Indianapolis, Indiana, U.S. & & June 24 & June 16 & June 12 & June 13 \\
\hline Sahm Park & $39^{\circ} 55^{\prime} 01.7^{\prime \prime} \mathrm{N}, 86^{\circ} 03^{\prime} 27.8^{\prime \prime} \mathrm{W}$ & & & & \\
\hline Sahm Golf Course & $39^{\circ} 54^{\prime} 58.0^{\prime \prime} \mathrm{N}, 86^{\circ} 03^{\prime} 12.8^{\prime \prime} \mathrm{W}$ & & & & \\
\hline Holland Park & $39^{\circ} 57^{\prime} 56.5^{\prime \prime} \mathrm{N}, 86^{\circ} 01^{\prime} 14.6^{\prime \prime} \mathrm{W}$ & & & & \\
\hline Flowing Well Park & $39^{\circ} 57^{\prime} 24.4^{\prime \prime} \mathrm{N}, 86^{\circ} 05^{\prime} 01.8^{\prime \prime} \mathrm{W}$ & & & & \\
\hline
\end{tabular}


the vigor class at first sighting of $\mathrm{EAB}$ was recorded for all trees in the study that had at least one EAB emergence hole on the basal $2 \mathrm{~m}$ of the trunk. The mean vigor class at first EAB sighting was compared for each year in Lafayette and Indianapolis using Friedman ANOVA. Understanding the vigor class of trees when they are first attacked by EAB can inform early detection efforts for this destructive pest.

To determine if tree size influenced the number of EAB emergence holes, a regression analysis was performed using the $\mathrm{DBH}$ of each tree. Researchers analyzed how vigor ranking and $\mathrm{DBH}$ influence the number of EAB emergence holes using a general linear model. These analyses were performed separately for each year of the study.

To determine the extent to which vigor class influenced the rate at which previously infested trees were attacked by EAB the following year, researchers calculated the rate of reinfestation of each tree by EAB. The number of new EAB emergence holes in trees previously infested by $\mathrm{EAB}$ was compared for each vigor class in each year using Kruskal-Wallis ANOVA in the Indianapolis site. Too few trees were infested with $\mathrm{EAB}$ at the Lafayette site to perform this analysis.

Spearman correlation analysis was performed to determine the extent to which the number of $\mathrm{EAB}$ emergence holes correlated with that of native borers each year. If $\mathrm{EAB}$ preferentially attacks trees previously colonized by native borers, then emergence holes of native borers may serve as predictors of EAB colonization. The effect of vigor class on the annual emergence of each type of borer was analyzed using Kruskal-Wallis ANOVA separately for each year. Year 2010 was excluded from this analysis because emergence holes in that year represent insect emergence from all years prior to the study. Too few trees were infested with $\mathrm{EAB}$ at the Lafayette site to perform this analysis.

The effect of individual indicators of tree vigor on EAB emergence was analyzed using KruskalWallis ANOVA. Because assessments occurred after the peak flight period of EAB, ratings of crown thinning, epicormic shoots, woodpecker damage (including holes and flecking), and vertical splits in one year were compared on the basis of the number of new $\mathrm{EAB}$ emergence holes observed in the following year. In this way, the study authors were able to understand how these individual indicators of tree vigor influence $\mathrm{EAB}$ attack by measuring emergence of the next generation.

\section{RESULTS}

By 2013, 92\% of ash trees at the Indianapolis site had declined to the Critical vigor class, compared to only an $8 \%$ decline of ash trees in Lafayette. Each year there was a significant decrease in the mean vigor class of trees in Indianapolis $\left(\chi_{(3,151)}^{2}=380.73, P<\right.$ 0.001 ) (Figure 1). There was no difference in the mean vigor class of Lafayette ash trees from 2010 through 2012 , but vigor began to decline in $2013\left(\chi_{(3,159)}^{2}=\right.$ $186.85, P<0.001)$. EAB was first detected in Lafayette in 2011 and is associated with the observed decline in vigor. Overall decline in vigor to the Critical category was much more pronounced in Indianapolis than Lafayette $(\log$-rank test $=-24.91, P<0.001)$.

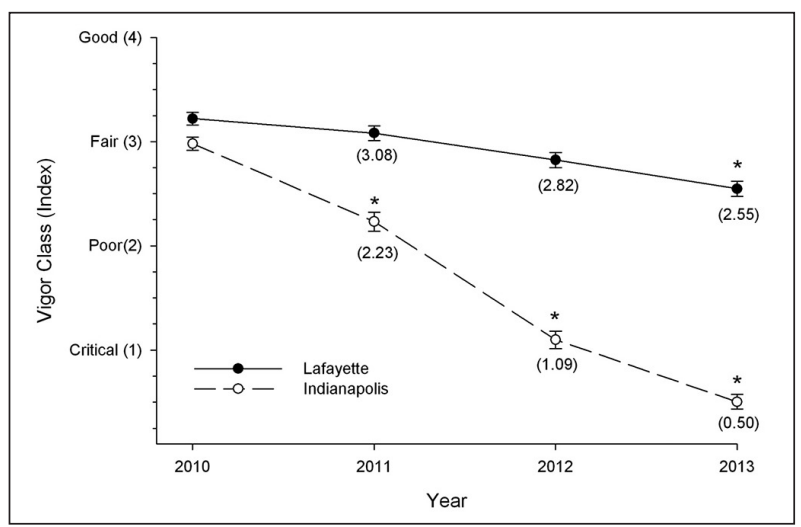

Figure 1. Mean vigor class $( \pm \mathrm{SE})$ of ash trees in Lafayette (without EAB) and Indianapolis (with EAB). Points marked with an asterisk are significantly different from the previous year (Friedman ANOVA, $P<0.05$ ).

The mean vigor class of trees at first detection of $\mathrm{EAB}$ decreased over the course of the study (Figure 2). In Lafayette, EAB was first detected in 2011 in a tree that was rated as Fair. In 2012, three more Fair trees and one Good tree were confirmed to be infested, and an additional Fair tree and eight Poor trees contained $\mathrm{EAB}$ emergence holes in $2013\left(\chi_{(1,4)}^{2}=4.0, P<0.05\right)$. In Indianapolis, the mean vigor class of a tree when emergence holes were first observed was between Fair and Poor in 2010, but by the second year of the study in 2011, the mean vigor ranking dropped below the Poor class and continued to decline in $2012\left(\chi_{(2,24)}^{2}=42.77, P<0.001\right)$. There was no correlation between the number of EAB emer- 
gence holes and the size of the tree, even when grouped by vigor class $(P>0.05$, data not shown).

When ash trees died or reached critical condition in Indianapolis, the number of $\mathrm{EAB}$ emergence holes decreased, compared with the previous year (Figure 3). In both 2010 and 2011, Poor trees had higher rates of reinfestation than Fair trees $\left(\mathrm{H}_{(2,39)}=11.24, P<0.0 ; \mathrm{H}_{(3,51)}\right.$ $=13.5, P<0.05$, respectively). The lowest rates of reinfestation were observed in 2012 because most of the trees were dead the following year.

The presence of emergence holes made by all native borers combined was correlated with $\mathrm{EAB}$ emergence holes in Indianapolis (Table 3). Long-

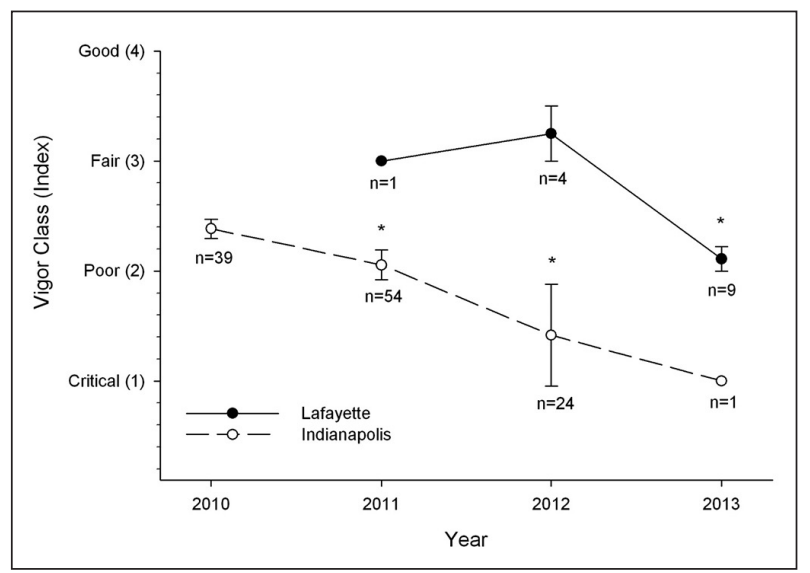

Figure 2. Mean vigor class ( $\pm S E$ ) of ash trees when EAB was first detected in Lafayette (without EAB in 2010) and Indianapolis (with EAB in 2010). Points marked with an asterisk are significantly different from the previous year (Friedman ANOVA, $P<0.05$ ).

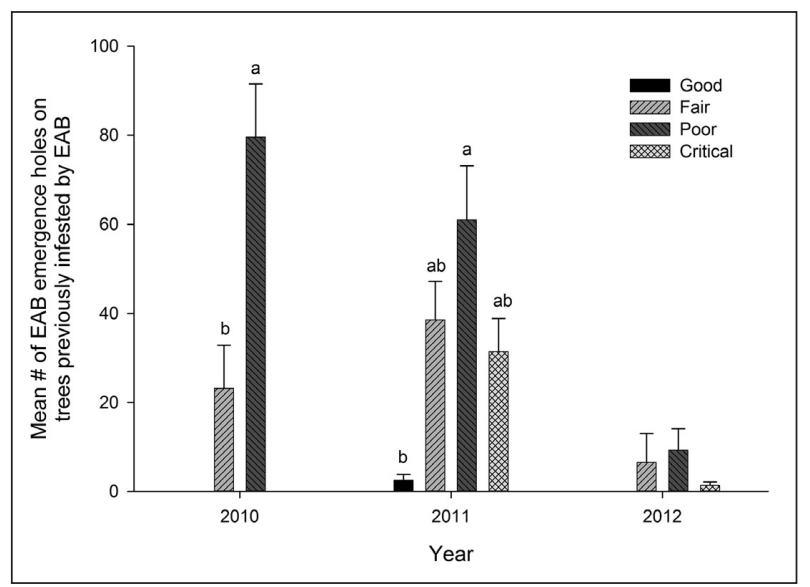

Figure 3. Mean number of new EAB emergence holes in trees of different vigor classes that were infested the previous year. Bars marked with the same letter are not significantly different (Kruskal-Wallis ANOVA, $P<0.05$ ).
Table 3. Spearman correlation coefficients comparing number of emerald ash borer emergence holes to those of native borers and bark beetles in each year of the study in Indianapolis.

\begin{tabular}{llllll}
\hline Year & $\begin{array}{l}\text { Longhorned } \\
\text { beetles }\end{array}$ & $\begin{array}{l}\text { Clearwing } \\
\text { borers }\end{array}$ & $\begin{array}{l}\text { Carpenter } \\
\text { worms }\end{array}$ & $\begin{array}{l}\text { Bark } \\
\text { beetles }\end{array}$ & $\begin{array}{l}\text { All native } \\
\text { borers }\end{array}$ \\
\hline 2010 & $0.17^{*}$ & 0.12 & 0.00 & -0.05 & $0.18^{*}$ \\
2011 & $0.25^{*}$ & 0.06 & -0.09 & 0.07 & $0.29^{*}$ \\
2012 & 0.07 & 0.15 & 0.00 & $0.25^{*}$ & $0.22^{*}$ \\
2013 & -0.22 & 0.39 & 0.00 & 0.00 & 0.29 \\
\hline
\end{tabular}

Note: Asterisk $\left.{ }^{*}\right)$ indicates $P<0.05$.

horned beetle holes were positively correlated with EAB holes in 2010 (Spearman $\mathrm{r}=0.17, P<0.05$ ) and 2011 (Spearman $\mathrm{r}=0.25, P<0.05$ ). Bark beetle emergence holes were positively correlated with $\mathrm{EAB}$ emergence holes in 2012 (Spearman $\mathrm{r}=$ $0.25, P<0.05)$. For the years $2010-2012$ there was a correlation between total native borer holes and EAB emergence holes (Spearman $r=0.17,0.29$, and 0.22 , respectively, $P<0.05$ ), but there were no correlations between any native borer and $\mathrm{EAB}$ in 2013 because most of the trees were already dead.

The effect of vigor class on the number of emergence holes differed by taxon. Ash bark beetles and carpenter worms were not found in large enough numbers for statistical analysis at either site. In Lafayette, there was no difference in the number of longhorned beetle emergence holes between the vigor classes for any year $\left(2011, \mathrm{H}_{(3,156)}=4.40, P=\right.$ $0.22 ; 2012, \mathrm{H}_{(3,154)}=2.46, P=0.48 ; 2013, \mathrm{H}_{(3,145)}=$ $0.30, P=0.96$; Figure $4 \mathrm{a})$. In Indianapolis, longhorned beetle emergence holes were found in greater abundance on trees in the Poor and Critical vigor classes in $2011\left(\mathrm{H}_{(3,147)}=8.47, P<0.05\right.$; Figure $4 \mathrm{~b}$ ). Clearwing borers were most abundant in Poor and Critical trees in Lafayette in $2011\left(\mathrm{H}_{(3,156)}\right.$ $=8.93, P<0.05)$ and on Poor trees alone in 2012 $\left(\mathrm{H}_{(3,154)}=16.32, P<0.05\right.$; Figure $\left.5 \mathrm{c}\right)$. In Indianapolis, there was no difference in the number of clearwing borers across vigor classes until 2013 where they were more abundant on Poor and Critical trees $\left(\mathrm{H}_{(3,23)}=9.97, P<0.05\right.$; Figure $\left.4 \mathrm{~d}\right)$. In Lafayette, vigor class did not influence the abundance of $\mathrm{EAB}$ (2011, $\mathrm{H}_{(3,156)}=1.79, P=0.62 ; 2012, \mathrm{H}_{(3,154)}=2.93$, $P=0.40 ; 2013, \mathrm{H}_{(3,146)}=6.07, P=0.11$; Figure $\left.4 \mathrm{e}\right)$. EAB emergence holes were most abundant in Indianapolis in trees rated Critical in 2011 and 2012 $\left(2011, \mathrm{H}_{(3,147)}=65.43, P<0.001 ; 2012, \mathrm{H}_{(3,93)}=21.55\right.$, $P<0.001$ ), but there was no difference in the number of emergence holes in 2013 when most of the trees were dead $\left(\mathrm{H}_{(3,23)}=4.10, P=0.25\right.$; Figure $\left.4 \mathrm{f}\right)$. 


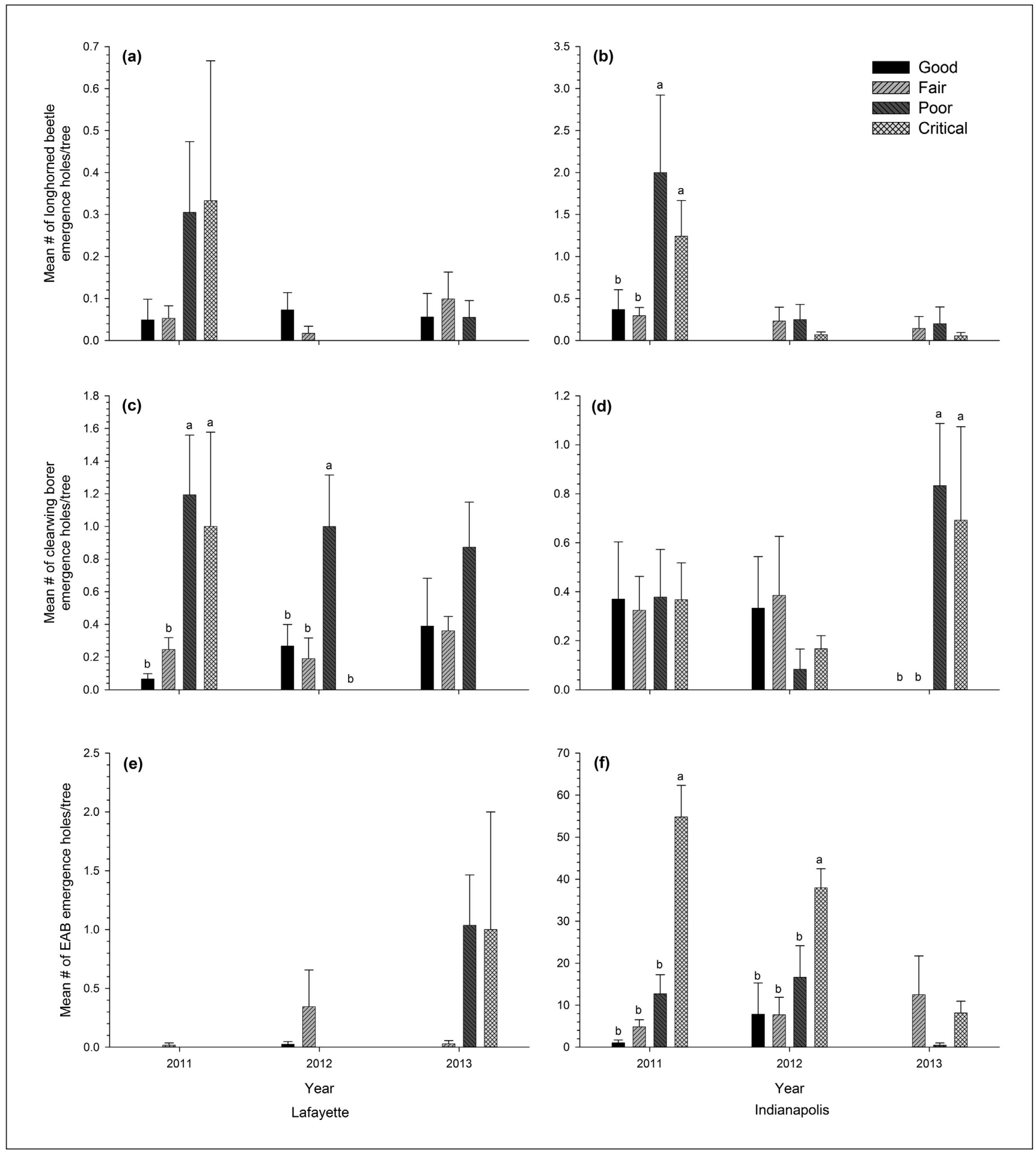

Figure 4. Mean number of new emergence holes from (a) redheaded ash borer in Lafayette and (b) Indianapolis, (c) clearwing borers in Lafayette and (d) Indianapolis, (e) EAB in Lafayette and (f) Indianapolis found in trees of each vigor class throughout the study. Comparisons were made only within sites and within the same year. Bars marked with a different letter are significantly different (Kruskal-Wallis ANOVA, $P<0.05$ ). 
Individual indicators of tree vigor influenced EAB emergence in Indianapolis the following year. Specifically, canopy thinning greater than $30 \%$ in 2010 was correlated with more EAB emergence holes in $2011\left(\mathrm{H}_{(3,47)}=56.96, P<0.001\right.$; Figure $5 a)$. EAB emergence holes in 2012 were greatest in trees that showed greater than $10 \%$ thinning the previous year $\left(\mathrm{H}_{(3,91)}=25.32, P<0.001\right)$. However, there was no correlation between canopy thinning and $\mathrm{EAB}$ emergence in $2013\left(\mathrm{H}_{(3,21)}=\right.$ 3.52, $P=0.32$ ) because many of the survey trees died in 2012 or 2013, and EAB cannot complete development in a dead tree. Trees with an abundance of epicormic shoots in 2010 had greater numbers of $\mathrm{EAB}$ emergence holes the following year than those with little or no epicormic sprouting $\left(\mathrm{H}_{(2,147)}=30.64, P<0.001\right.$; Figure $\left.5 \mathrm{~b}\right)$. Trees with an abundance of woodpecker damage had more EAB emergence holes in 2011 than those with no woodpecker damage $\left(\mathrm{H}_{(2,147)}=13.9, P<\right.$
0.05; Figure 5c). EAB emergence holes were most abundant in 2012 on trees that had many bark splits in $2011\left(\mathrm{H}_{(2,91)}=11.90, P<0.05\right.$; Figure $\left.5 \mathrm{~d}\right)$.

\section{DISCUSSION}

The key to controlling any invasive insect pest is early detection and rapid response. The spread of EAB to a new area can be described as an invasion wave (Burr 2012). During the first few years of invasion, the population level of EAB is low and the proportion of attacked trees is small, representing the cusp portion of the wave. This period of slow population growth is the best opportunity for aggressive management, such as the responsible use of insecticides. From year three or four after colonization, the rate of population growth increases exponentially into the crest of the wave, and management of the pest becomes more difficult and expensive (Burr and McCullough 2012). However, the current assessment scheme enabled

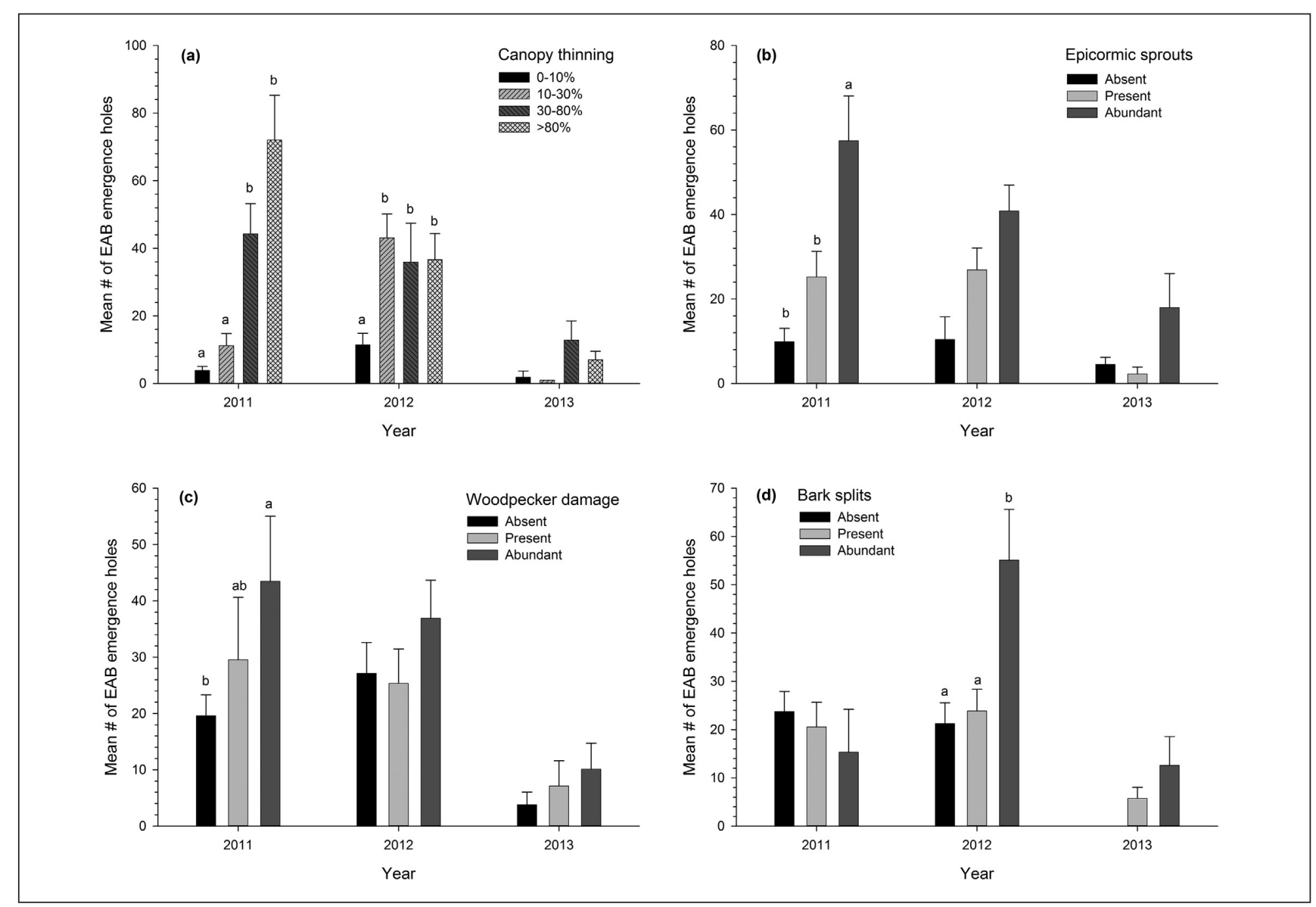

Figure 5. Mean number of new EAB emergence holes in each year of the study in Indianapolis for factors that are general predictors of EAB in the previous year: (a) canopy thinning, (b) epicormic sprouts, (c) woodpecker damage, and (d) bark splits (Kruskal-Wallis ANOVA, $P<0.05)$. 
researchers to detect $\mathrm{EAB}$ early in the invasion, before trees began to decline in health in Lafayette. This early detection is likely attributable to annual surveys, underscoring the importance of examining threatened street trees in regions where $\mathrm{EAB}$ infestations have been reported. The use of visual surveys by trained arborists and urban foresters could drastically reduce the time between EAB colonization and their detection in an urban forest. One hundred fifty-nine ash trees were surveyed, only a subset of the 1,500 ash street trees in the greater Lafayette area, which drastically reduced time spent in the field. Moreover, such visual surveys are also faster and less costly than using girdled trap trees where the bark must be carefully removed to count larvae at the end of the season (Cappaert et al. 2005).

Analysis of ash decline during the course of this study is consistent with the wave analogy. The vigor of ash trees declined faster in Indianapolis than in Lafayette (Figure 1). However, trees in Lafayette began to decline more rapidly the year after EAB was detected (Figure 2). Moreover, in the third year, EAB was more likely to be detected in Lafayette in trees of poor quality. Interestingly, at the end of the study, trees in Lafayette displayed an average vigor ranking similar to trees in Indianapolis two years prior, suggesting that Lafayette is entering the crest phase of the invasion. The decline among sentinel trees in the more recently infested Lafayette area may serve as a warning that EAB population levels are growing, and action must be taken to save ash trees and to protect the urban forest.

A limitation of the visual assessment scheme is that it does not account for EAB infesting higher portions of the main stem and branches of the canopy. For taller trees, inspecting the basal two meters of the bole will not account for emergence holes higher in the tree, and using binoculars to survey the canopy might yield earlier detection of EAB (Smitley et al. 2008). Nevertheless, the majority of street trees in Midwestern U.S. cities are small or young (Peper et al. 2008; Nowak et al. 2013), and street trees in urban settings often grow slower than those in natural forests (Iakovoglou et al. 2001). In fact, only a few street trees in the current study had a bole greater than two meters. In these smaller trees, EAB may attack the bole earlier, making surveys of this portion of the trunk more informative for early detection efforts. Using the visual assessment scheme in Lafayette, for example, researchers were able to detect EAB emergence holes on the lower bole of apparently healthy trees, suggesting that the method of rapid assessment is capable of detecting an emerging EAB invasion even before trees begin to show signs of decline.

In this study, tree vigor influenced the colonization behavior of $\mathrm{EAB}$, supporting hypotheses that it can be a putative predictor of EAB attack in areas with an active infestation (McCullough et al. 2009a; McCullough et al. 2009b). Stress predisposes Asian ash trees to attack by EAB in its native range (Yu 1992), and $\mathrm{EAB}$ are more attracted to girdled and herbicide-treated ash trees than healthy trees (Poland et al. 2005; Marshall et al. 2009; McCullough et al. 2009a; McCullough et al. 2009b). Moreover, EAB often attacks trees that have already been colonized, as demonstrated by data from the Indianapolis sites. Larvae may even improve the suitability of a tree for further infestation as they feed, stressing the tree and making it more attractive through changes in its volatile profiles (Rodriguez-Saona et al. 2006) or by increasing the nutritional quality of the host. Likewise, native Agrilus beetles in North America also attack stressed trees. Oaks (Quercus spp.) and birches (Betula spp.) are susceptible to $A$. bilineatus and $A$. anxius, respectively, when stressed by drought and other factors (Anderson 1944; Haack and Benjamin 1982; Dunn et al. 1986; Dunn et al. 1987; Katovich et al. 2001).

Of the general predictors of EAB, canopy thinning was positively correlated with EAB emergence holes (Figure 5). Epicormic sprouts, woodpecker damage, and bark splits had little relationship with $\mathrm{EAB}$ emergence holes and may be less useful for early detection efforts. Canopy thinning is closely associated with the vigor ranking system, but it may be a valuable predictor on its own. However, canopy thinning is a symptom of many biotic and abiotic stresses, including drought. Thus, care should be taken when using canopy thinning to detect emerald ash borer in urban trees.

Researchers also found that apparently healthy trees are susceptible to EAB. Using the borerspecific assessment scheme, the first incidence of EAB was identified in Lafayette, Indiana. In 2011, one tree rated as Fair was found to have EAB, and 
in 2012 three more Fair trees and one Good tree were confirmed to be infested. Although EAB likely prefers stressed trees, little is known about its preference for trees of naturally varying health in an urban forest. Data indicate that EAB may attack trees that are apparently healthy according to tree vigor ranking schemes used by urban foresters. If efforts are focused only on those trees that appear to be stressed, incipient populations of EAB may go undetected for several years longer than if Good and Fair trees are also included in the survey.

Observations of borer-associated symptoms also confirm other findings that canopy thinning, epicormic sprouting, woodpecker damage, and bark splitting can be strongly associated with the abundance of $\mathrm{EAB}$ as the forest enters the crest stage of EAB colonization. Moreover, canopy thinning is correlated with EAB in the earlier cusp phase of the invasion, and may be important for evaluating the status of EAB in urban forests before ash trees begin to die. Arborists can use this scheme to select sentinel ash trees of varying vigor classes and monitor these trees for EAB-related decline to provide essential data that may convince municipalities to initiate timely management efforts.

Acknowledgments. We thank Gary Frazier, Matthew Paschen, Lindsay Patrick, Donnie Peterson, Julia Prado, Carlos Quesada, Katie Strack, Nicole VanDerLaan, Adam Witte and Chelsea Wood of Purdue University for their assistance rating ash trees. We thank Lindsey Purcell of Purdue University for his assistance in developing our tree vigor assessment scheme. Special thanks is extended to Bev Shaw (City of West Lafayette), Belinda Kiger (City of Lafayette), Andrew Mertz and Paul Pinco (City of Indianapolis Parks Department), and Daren Mindham (City of Carmel) for helping us secure access to Indianapolis and Lafayette area trees. Funding was provided by USDA-NIFA grant \#2010-41530-21043. This research was conducted in partial fulfillment of a Ph.D. for G.P.H. from Purdue University.

\section{LITERATURE CITED}

Anderson, R.F. 1944. The relation between host condition and attacks by the bronzed birch borer. Journal of Economic Entomology 37:588-596.

Burr, S.J. 2012. Evaluation of emerald ash borer populations and the ash resource at three stages of the invasion wave. M.Sc. thesis, Michigan State University, East Lansing, Michigan, U.S. 77 pp.

Burr, S.J., and D.G. McCullough. 2012. The future of green ash behind, within, and ahead of the advancing front of emerald ash borer. In: K. McManus and K.W. Gottschalk (Eds.). Twenty-third U.S. Department of Agriculture Interagency Research Forum on Invasive Species 2012. Gen. Tech. Rep. NRS-P-114, p. 72.

Cappaert, D., D.G. McCullough, T.M. Poland, and N.W. Siegert. 2005. Emerald ash borer in North America: A research and regulatory challenge. American Entomologist 51:152-165.
Crook, D., J.A. Khrimian, J.A. Francese, I. Fraser, T.M. Poland, and V.C. Mastro. 2008. Development of a host-based semiochemical lure for trapping emerald ash borer, Agrilus planipennis (Coleoptera: Buprestidae). Environmental Entomology 37:356-365.

de Groot, P., G.G. Grant, T.M. Poland, R. Scharbach, L. Buchan, R.W. Nott, L. Macdonald, and D. Pitt. 2008. Electrophysiological response and attraction of emerald ash borer to green leaf volatiles (GLVs) emitted by host foliage. Journal of Chemical Ecology 34:1170-1179.

Dunn, J.P., T.W. Kimmerer, and G.L. Nordin. 1986. Attraction of the twolined chestnut borer, Agrilus bilineatus (Weber) (Coleoptera: Buprestidae) and associated borers to volatiles of stressed white oak. Canadian Entomologist 118:503-509.

Dunn, J.P., T.W. Kimmerer, and D.A. Potter. 1987. Winter starch reserves of white oak as a predictor of attack by the twolined chestnut borer, Agrilus bilineatus (Weber) (Coleoptera: Buprestidae). Oecologia 74:352-355.

Fierke, M.K., D.L. Kinney, V.B. Salisbury, D.J. Crook, and F.M. Stephen. 2005. A rapid estimation procedure for within-tree populations of red oak borer (Coleoptera: Cerambycidae). Forest Ecology and Management 215:163-168.

Haack, R.A., and D.M. Benjamin. 1982. The biology and ecology of the twolined chestnut borer, Agrilus bilineatus (Coleoptera: Buprestidae), on oaks, Quercus spp., in Wisconsin. Canadian Entomologist 114:385-396.

Haack, R.A., E. Jendek, H. Liu, K.R. Marchant, T.R. Petrice, T.M. Poland, and H. Ye. 2002. The emerald ash borer: A new exotic pest in North America. Newsletter of the Michigan Entomological Society 47(3-4):1-5.

Herms, D.A., D.G. McCullough, D.R. Smitley, C.S. Sadof, and W. Cranshaw. 2014. Insecticide options for protecting trees from emerald ash borer. North Central IPM Center Bulletin. Second edition. 16 pp.

Iakovoglou, V., J. Thompson, L. Burras, and R. Kipper. 2001. Factors related to tree growth across urban-rural gradients in the Midwest, USA. Urban Ecosystems 5:71-85.

ISA (International Society of Arboriculture). 2013. ISA Basic Tree Risk Assessment Form. Accessed 03/26/2014. <www.isa-arbor. com/education/resources/BasicTreeRiskAssessmentForm_ FirstEdition.pdf>

Kaplan, E.L., and P. Meier. 1958. Nonparametric estimation from incomplete observations. Journal of the American Statistical Association 53:457-481.

Katovich, S.A., A.S. Munson, J. Ball, and D. McCullough. 2001. Bronze birch borer. U.S. For. Serv. For. Insect Dis. Leafl. No. 111.

Knight, K.S., J.P. Brown, and R.P. Long. 2013. Factors affecting the survival of ash (Fraxinus spp.) trees infested by emerald ash borer (Agrilus planipennis). Biological Invasions 15:371-383.

Kovacs, K.F., R.J. Mercader, R.G. Haight, N.W. Siegert, D.G. McCullough, and A.M. Liebhold. 2010. Cost of potential emerald ash borer damage in U.S. communities, 2009-2019. Ecological Economics 69:569-578.

Liu, H., L.S. Bauer, D.L. Miller, T. Zhao, R. Gao, L. Song, Q. Luan, R. Jin, and C. Gao. 2007. Seasonal abundance of Agrilus planipennis (Coleoptera: Buprestidae) and its natural enemies Oobius agrili (Hymenoptera: Encyrtidae) and Tetrastichus planipennisi (Hymenoptera: Eulophidae) in China. Biological Control 42:61-71.

Lyons, D.B., and G.C. Jones. 2005. The biology and phenology of the emerald ash borer. In: K.W. Gottschalk (Ed.). Proceedings, 16th U.S. Department of Agriculture Interagency Research Forum on Gypsy Moth and Other Invasive Species, p. 62. USDA 
Forest Service, Northeastern Research Station, Gen. Tech. Rep. NE-332. 98 pp.

Marshall, J.M., A.J. Storer, I. Fraser, J.A. Beachy, and V.C. Mastro. 2009. Effectiveness of differing trap types for the detection of emerald ash borer (Coleoptera: Buprestidae). Environmental Entomology 38:1226-1234.

McCullough, D.G., and R.J. Mercader. 2012. Evaluation of potential strategies to SLow Ash Mortality (SLAM) caused by emerald ash borer (Agrilus planipennis): SLAM in an urban forest. International Journal of Pest Management 58:9-23.

McCullough, D.G., T.M. Poland, A.C. Anulewicz, and D. Cappaert. 2009a. Emerald ash borer (Coleoptera: Buprestidae) attraction to stressed or baited ash trees. Environmental Entomology 38:1668-1679.

McCullough, D.G., T.M. Poland, and D. Cappaert. 2009b. Attraction of the emerald ash borer to ash trees stressed by girdling, herbicide treatment, or wounding. Canadian Journal of Forest Research 39:1331-1345.

Nowak, D.J., R.E. Hoehn III, A.R. Bodine, D.E. Crane, J.F. Dwyer, V. Bonnewell, and G. Watson. 2013. Urban trees and forests of the Chicago region. Resource Bulletin NRS-84 of the U.S. Forest Service Northern Research Station, Newton Square, Pennsylvania, U.S. 106 pp.

Peper,P.J.,E.G.McPherson,J.R.Simpson,K.E.Vargas, andQ.Xiao.2008. City of Indianapolis, Indiana Municipal Forest Resource Analysis. Center for Urban Forest Research. USDA Pacific Southwest Research Station. Accessed 02/13/2014. <www.fs.fed.us/psw/ programs/cufr/products/psw_cufr738_IND_MFRA.pdf>

Poland, T.M., and D.G. McCullough. 2006. Emerald ash borer: Invasion of the urban forest and the threat to North America's ash resource. Journal of Forestry 104:118-124.

Poland, T.M., D.G. McCullough, P. de Groot, G. Grant, L. MacDonald, and D.L. Cappaert. 2005. Progress toward developing trapping techniques for the emerald ash borer. In: V. Mastro and R. Reardon (Comps). Proceedings of the emerald ash borer research and development meeting 2004 October 5-6, Romulus, MI. FHTET 2004-15. Morgantown, WV: U.S. Forest Service, Forest Health Technology Enterprise Team: 53-54.
Raupp, M.J., A.B. Cumming, and E.C. Raupp. 2006. Street tree diversity in eastern North America and its potential for tree loss to exotic borers. Arboriculture \& Urban Forestry 32:297-304.

Rodriguez-Saona, C., T.M. Poland, J.R. Miller, L.L. Stelinski, G.G. Grant, P. De Groot, L. Buchan, and L. MacDonald. 2006. Behavioral and electrophysiological responses of the emerald ash borer, Agrilus planipennis, to induced volatiles of Manchurian ash, Fraxinus mandshurica. Chemoecology 16:75-86.

Smitley, D., T. Davis, and E. Rebek. 2008. Progression of ash canopy thinning and dieback outward from the initial infestation of emerald ash borer (Coleoptera: Buprestidae) in southeastern Michigan. Journal of Economic Entomology 101:1643-1650.

StatSoft, Inc. 2011. Statistica (Version 10) [Data analysis software system].

Wang, X., Y. Zhou, J.R. Gould, Y. Zhang, G. Liu, and E. Liu. 2010. The biology and ecology of the emerald ash borer, Agrilus planipennis, in China. Journal of Insect Science 10(128):1-23.

Yu, C. 1992. Agrilus marcopoli Obenberger (Coleoptera: Buprestidae). pp. 400-401. In: G.R. Xiao (Ed.). Forest insects of China, second edition. China Forestry Publishing House, Beijing, China.

Gabriel P. Hughes

Department of Entomology

Purdue University

West Lafayette, Indiana, 47907-2089, U.S.

Clifford S. Sadof

Department of Entomology

Purdue University

West Lafayette, Indiana, 47907-2089, U.S.

Matthew D. Ginzel (corresponding author)

Department of Entomology

Purdue University

West Lafayette, Indiana, 47907-2089, U.S.

mginzel@purdue.edu 
Résumé. Les insectes agressifs comme l'agrile du frêne [Agrilus planipennis (Fairmaire)] (AF) menacent de manière importante la santé des forêts urbaines. Le dépistage précoce des parasites xylophages exotiques est essentiel à une prompte intervention réactive et permet une prise en charge efficace alors que les populations parasitaires sont encore relativement faibles. Durant l'inventaire des arbres d'alignement, les arboriculteurs attribuent des cotes selon la condition des arbres et la présence ou non de ravageurs; l'étendue des dommages causés par ces derniers est cependant rarement établie. En outre, la corrélation entre l'appréciation de la vigueur des arbres par les professionnels au moment de l'inventaire et la probabilité d'une infestation d'insectes perceurs est inconnue. Dans cette étude, les chercheurs ont développé une méthode d'estimation de la vigueur des arbres affectés par des perceurs afin de rapidement évaluer les arbres d'alignement et d'identifier le moment où les populations de l'AF commencent à croître de façon exponentielle en fonction de l'état de santé constaté de la forêt. Cette méthode intègre des indicateurs bien connus d'attaques par l'agrile du frêne, y compris l'éclaircissage du houppier et l'apparition de pousses adventives, ainsi que la présence d'insectes perceurs indigènes communs. Cette méthode a été utilisée de 2010 à 2013 pour évaluer la santé des frênes d'une forêt urbaine exhibant des symptômes significatifs d'un déclin occasionné par l'agrile du frêne et d'une autre forêt n'affichant pas de tels symptômes ou déclin (respectivement Indianapolis et Lafayette, toutes deux en Indiana). Les arbres ont dépéri plus rapidement à Indianapolis alors que les trous d'émergence des perceurs indigènes étaient corrélées de manière positive avec la présence d'agriles du frêne dans les zones infestées. En cours de réalisation de l'étude, il a été observé que les premières détections de l'agrile du frêne sont apparues progressivement sur les arbres les plus faibles des deux sites, suggérant ainsi que le dépistage précoce des populations naissantes d'AF peut être amélioré en examinant des arbres apparemment en bonne santé.

Zusammenfassung. Aggressive Insekten, wie der Smaragdgrüne Eschenprachtkäfer [Agrilus planipennis (Fairmaire)] (EAB) beeinträchtigen zunehmend die Gesundheit der urbanen Forste. Eine frühzeitige Erkennung von exotischen holzbohrenden Schädlingen ist der kritische Punkt für schnelle Reaktionen und Genehmigungen für effektives Management, während die Populationen noch relativ klein sind. Bei den Datenerfassungen in Baumkatastern verzeichnen die Arboristen subjektive Bewertungen zur Baumkondition und Anzeichen für Schädlingsbefall, dennoch wird das Ausmaß einer Insektenattacke selten quantifiziert. Mehr noch: es ist unbekannt, wie die Untersuchung der Baumvitalität durch die Forstleute während der Baumerfassung zu einer Wahrscheinlichkeit einer Infektion durch Bohrinsekten in Beziehung steht. In dieser Studie entwickelten die Forscher ein Bohrer-spezifisches
Baumvitalitätsbestimmungsschema, um schnell Straßenbäume zu bewerten und um zu identifizieren, wann auf der Basis von Erkenntnissen zur Gesundheit des Waldes die EAB-Populationen exponentiell zu wachsen beginnen. Dieses Schema enthält gewöhnliche Indikatoren einer EAB-Attacke, einschließlich dünner werdender Kronen und epikormische Triebe (aus schlafenden Knospen) und auch Attacken aus einheimischen holzbohrenden Insekten. Dieses Schema wurde verwendet, um die Gesundheit von Eschen im Zeitraum von 2010-2013 in einem urbanen Forst mit fortgeschrittenen Symptomen von EAB Rückgang und einem ohne Symptome (Indianapolis und Lafayette, Indiana, U.S.) zu testen. In Indianapolis starben die Bäume schneller, wo die Ausschlupflöcher von einheimischen Bohrinsekten positiv mit EAB in infizierten Bereichen korreliert werden konnten. Im Verlauf der Studie tauchten an beiden Standorten die ersten Anzeichen von EAB an progressiv geschwächten Bäumen auf, und zeigten, dass eine frühe Erkennung von beginnenden EAB-Populationen durch die Überwachung von scheinbar gesunden Bäumen verbessert werden kann.

Resumen. Insectos agresivos como el barrenador esmeralda del fresno [Agrilus planipennis (Fairmaire)] (EAB) amenazan cada vez más la salud de los bosques urbanos. La detección temprana de plagas exóticas de barrenadores de la madera es fundamental para una respuesta rápida y permite una gestión eficaz mientras que las poblaciones estén relativamente bajas. Durante los inventarios de árboles urbanos lo arboristas hacen evaluaciones de la condición de los árboles y la incidencia de las plagas; sin embargo, la extensión del ataque rara vez se cuantifica. Por otra parte, no se sabe cómo se evalúa el vigor del árbol por los dasónomos urbanos durante estos inventarios con relación a la probabilidad de infestación por el barrenador. En este estudio, los investigadores desarrollaron un proyecto de valoración específico de vigor del árbol con el fin de evaluar rápidamente árboles y para identificar cuando las poblaciones $\mathrm{EAB}$ comienzan a crecer de forma exponencial en base a la salud del bosque. Este esquema incorpora indicadores comunes de ataque de $\mathrm{EAB}$, incluyendo el aclareo del dosel y brotes epicórmicos, así como el ataque de insectos xilófagos nativos comunes. Este diseño fue usado para realizar un seguimiento de la salud de los fresnos de 2010 a 2013 en un bosque urbano con síntomas avanzados de $\mathrm{EAB}$ y uno sin ataque (Indianápolis y Lafayette, Indiana, Estados Unidos, respectivamente). Los árboles declinaron más rápidamente en Indianápolis, donde los agujeros de emergencia de barrenadores nativos se correlacionaron positivamente con EAB en áreas infestadas. En el transcurso del estudio, las primeras detecciones de $\mathrm{EAB}$ se produjeron en los árboles progresivamente más débiles en ambos sitios, lo que sugiere que la detección temprana de las poblaciones incipientes de EAB se puede mejorar mediante una encuesta árboles aparentemente sanos. 